\title{
Variation in growth, yield and protein concentration in Saccharina latissima (Laminariales, Phaeophyceae) cultivated with different wave and current exposures in the Faroe Islands
}

\author{
Agnes Mols-Mortensen $^{1,2}$ (D) E Elma á Geilini Ortind ${ }^{1,3} \cdot$ Charlotte Jacobsen $^{4}$. \\ Susan Lovstad Holdt ${ }^{4}$
}

Received: 17 October 2016 / Revised and accepted: 9 May 2017 /Published online: 1 June 2017

(C) The Author(s) 2017. This article is an open access publication

\begin{abstract}
Ropes seeded directly with Saccharina latissima were deployed at different exposures (sheltered, current exposed and wave exposed) in a Faroese sound and characteristics of growth and quality of the biomass and surroundings were evaluated during the growth season from March to August 2015. Saccharina latissima individuals cultivated at the current exposed location were heavier compared to the individuals cultivated at the other locations; however, the total biomass yield was significantly lower at the current exposed location. The protein and nutritional value of the biomass varied with season but showed no correlation with exposure. The highest protein levels and EAA (essential amino acid) score were measured in the spring (April and May) samples. The amino acid composition was dominated by glutamate followed by aspartic acid; however, this was replaced by methionine in the July samples. Total Kjeldahl nitrogen was significantly higher in May and August compared to July, and the nitrate concentration in the biomass was significantly lower in May and August compared to July. Nitrate was most available in the seawater at the time of deployment (3rd of March) and decreased during spring and summer. Saccharina latissima was cultivated successfully at the sheltered, current exposed and wave exposed locations using a direct seeding method. However, our results indicate that the lower biomass yield at
\end{abstract}

Agnes Mols-Mortensen

agnesmols@ fiskaaling.fo

1 Fiskaaling-Aquaculture Research Station of the Faroes, 430 Hvalvík, Faroe Islands

2 TARI-Faroe Seaweed, 100 Tórshavn, Faroe Islands

3 Faroese Food- and Veterinary Agency, 100 Tórshavn, Faroe Islands

4 National Food Institute, Technological University of Denmark, 2800 kongens Lyngby, Denmark the current exposed cultivation location compared to the sheltered and wave exposed are due to the direct seeding method, and possible limitations using this method need further testing and optimization.

Keywords Chemical composition - Cultivation - Essential amino acids $\cdot$ Exposure $\cdot$ Saccharina latissima .

Phaeophyceae $\cdot$ Seasonality

\section{Introduction}

Macroalgal cultivation is a developing industry in the Western part of the world, and there is a growing interest in utilizing the produced biomass for both food, feed and raw material input into biorefinery processes including extraction of high added value bioactive compounds (e.g. Hughes et al. 2012; Holdt and Kraan 2011). Experimental macroalgal cultivation including the brown algal species Alaria esculenta (Linnaeus) Greville and Saccharina latissima (Linnaeus) C.E. Lane, C. Mayes, Druehl \& G.W. Saunders has been ongoing in the Faroe Islands since 2005, and the cultivation is now becoming more commercialized, however, on a small scale (A. MolsMortensen pers. obs.).

Environmental conditions for macroalgal cultivation are relatively good in the Faroe Islands, and promising growth and yield potential have been observed for A. esculenta and S. latissima (Wegeberg et al. 2013; A. Mols-Mortensen pers. obs.). Optimal seawater temperatures for the growth of S. latissima sporophytes are between 10 and $15{ }^{\circ} \mathrm{C}$ (Fortes and Lüning 1980; Bolton and Lüning 1982; Lüning and Freshwater 1988), and the sporophyte growth slows down when seawater temperatures exceed $16{ }^{\circ} \mathrm{C}$ (Lee and Brinkhuis 1986). The seawater conditions around the Faroe Islands are fairly constant with a minimum temperature of just 
below $7{ }^{\circ} \mathrm{C}$ in winter (December to March) and a maximum of just above $10^{\circ} \mathrm{C}$ in late summer (August), and stable salinity of approx. 35\% (ENVOFAR 2015). The seawater temperatures do not exceed $11{ }^{\circ} \mathrm{C}$ in the Faroe Islands, and this fits well with the optimal conditions for S. latissima sporophyte growth. The nutrient concentrations in the Faroese fjords and sounds depend on the nutrient concentrations on the Faroe shelf and inflow to the fjords and sounds. Nitrate concentrations on the Faroe shelf during summer (May to September) range between 2.2 and 10.2 $\mu \mathrm{M}$ (Hansen et al. 2005; Gaard et al. 2006; Debes et al. 2008) but can vary from year to year (Gaard et al. 2011). The availability of nutrients varies with season, and the nitrate concentrations are generally lowest during summer. However, the stratification in the Faroese fjords is weak, and seawater exchange and the inflow of nutrients are high (Gaard et al. 2011).

Environmental conditions at a cultivation location affect productivity of the macroalgal crop. Water motion influences macroalgal production with positive correlation to the uptake of nutrients and carbon dioxide and also influences factors such as light attenuation and rate of herbivory that have consequences for the growth (Hurd 2000). In addition, water motion influences the morphology of the macroalgae (Hurd 2000; Peteiro and Freire 2013), and seasonality affects the chemical composition (Schiener et al. 2015). One important factor in developing a strong macroalgal industry is to locate the macroalgal farms in areas that are well suited for the biomass production.

The current work is the first attempt in Faroese waters to study how different exposures (sheltered, current exposed and wave exposed) and seasonality (spring and summer) influence the cultivation of S. latissima. The growth, yield and morphology (length and width of thalli, and stipe length incl. ratios) were measured through the growth period together with the Kjeldahl-nitrogen and nitrate concentration (biomass and ambient). The quality of the biomass was also evaluated with regard to protein concentration, amino acid composition and essential amino acid score, and the direct seeding method was assessed with regard to harvest yields at the different exposures.

\section{Materials and methods}

\section{Seeding and cultivation}

The cultivation methods used in this work were based on standard procedures (e.g. Edwards and Watson 2011). Fertile individuals of Saccharina latissima were collected by divers in Oyragjógv, Faroe Islands, on 9 January 2015. The sori areas on the lamina were cut out and cleaned mechanically with a brush using filtered and UV-treated seawater, and left to dry overnight on paper covered by black plastic at approx. $15^{\circ} \mathrm{C}$.
The spores were released and kept in aerated Pyrex flasks at $8{ }^{\circ} \mathrm{C}$ at the hatchery facility. The cultures were given long day conditions (16L/8D) and light intensity of approx. $100 \mu \mathrm{mol}$ photons $\mathrm{m}^{-2} \mathrm{~s}^{-1}$ (Dioflex LED strips 3000K). The seawater used in the cultures was filtered $(80 \mu \mathrm{m})$, skimmed in a protein skimmer and UV radiated with a minimum effect of $250 \mathrm{~J} \mathrm{~m}^{-2}$. Approximately one third of the seawater in the culture flasks was changed once a week, and the cultures were blended using a hand blender. After 40 days, sporophytes of two to ten cells in size were visible in the microscope. The sporophyte cultures were diluted to ca. 100 sporophytes $\mathrm{mL}^{-1}$ and seeded onto $12 \mathrm{~mm}$ thick and $2 \mathrm{~m}$ long ropes using a hand held sprayer. The ropes were seeded onboard the boat at the deployment location and deployed approx. 10 to $30 \mathrm{~min}$ after seeding on 3 March 2015. Sampling was carried out approx. every third week, and the last sampling and harvesting were carried out on 19 August 2015.

\section{Cultivation structure}

The cultivation structures consisted of a 12-m long horizontal main line that was fixed to the seafloor by anchors and held up by buoys. Five seeded ropes of $2 \mathrm{~m}$ (here after referred to as droplines) were attached to the main line and kept in a vertical position by a float at the top and a weight at the lower end.

\section{Cultivation locations}

Cultivation structures were deployed on three locations in Sundalagið, which is a sound between Streymoy and Eysturoy in the Faroe Islands (Fig. 1), and the locations differed with regard to exposure degree. The exposures of the locations were defined using available data on current and wind speed. The wind speed was based on the estimations of Simonsen (2015) on data from the weather station at Streymnes (www.lv.fo) in Sundalagið from 2010 to 2015 and set to the average wind speed for the months of cultivation (April to August). None of the locations were exposed to ocean waves (Mortensen et al. 2014a), and wave estimation was therefore based solely on wind waves. The wave heights $(H s)$ were estimated according to Simonsen (2015) and calculated using the equation $\mathrm{Hs}=5.112 \times 10^{-4} U_{A} F^{1 / 2}$ where $U_{A}$ is the adjusted wind speed $U_{A}=0.71 \mathrm{U}^{1.23}, U$ is the wind speed and $F$ is the wind fetch. The wind fetch in the main wind direction was found by measuring the distance between cultivation location and land using www.kortal.fo. The estimated wave heights based on wind speeds from the prevailing wind directions (SE and $\mathrm{W}$ ) were 0.6 and $0.2 \mathrm{~m}$ at the sheltered site, 0.9 and $0.2 \mathrm{~m}$ at the current exposed site and 2.2 and $1.0 \mathrm{~m}$ at the wave exposed site.

Location 1 was defined as the sheltered location with a current speed of $<5 \mathrm{~cm} \mathrm{~s}^{-1}$ approx. half of the time and an overall current speed of $<10 \mathrm{~cm} \mathrm{~s}^{-1}$. The maximum observed 


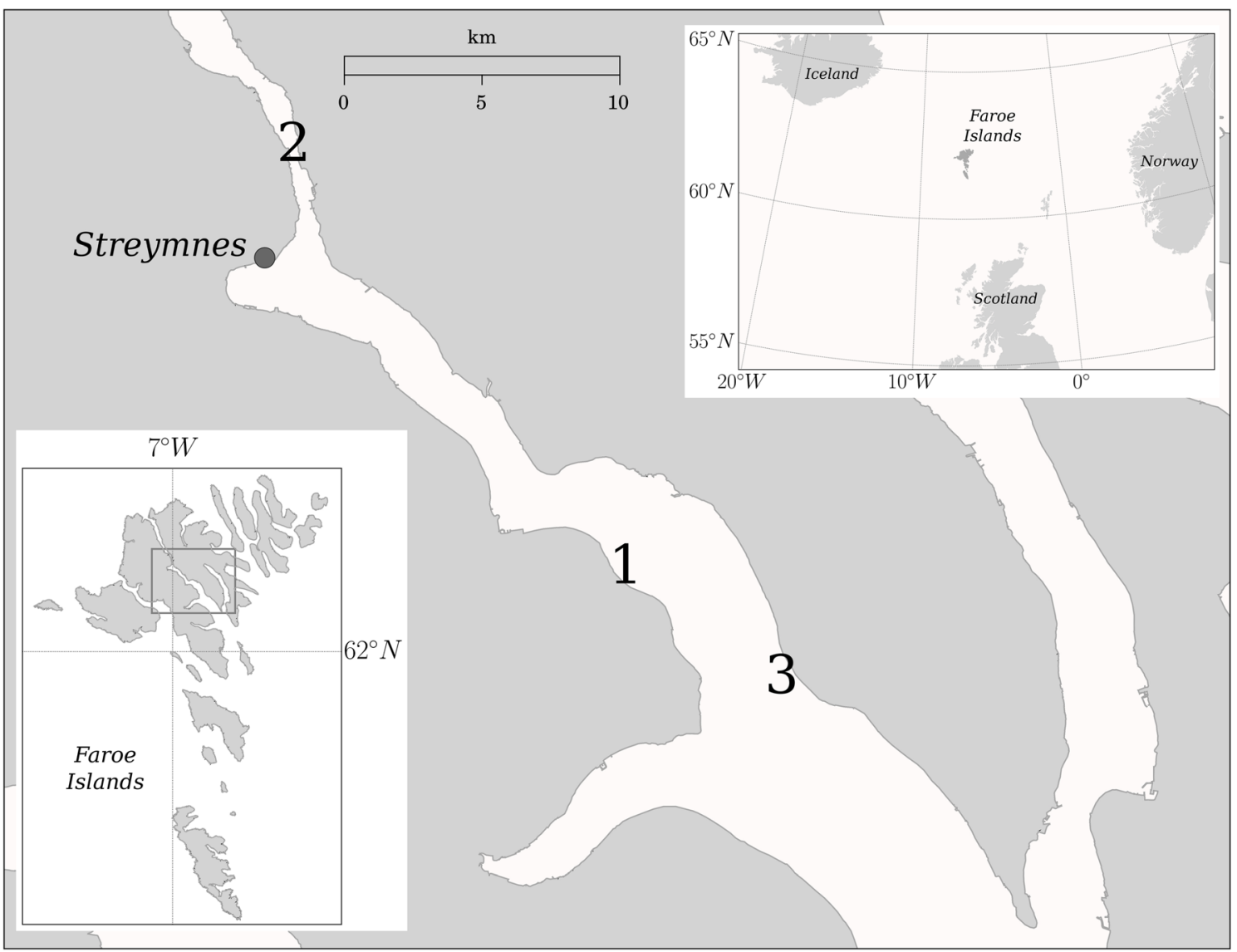

Fig. 1 Map showing the cultivation locations in the sound Sundalagio in the Faroe Islands. Number 1 indicates the sheltered location, 2 the current exposed location, and 3 the wave exposed location. Streymnes is the location of the weather station where the wind speed was measured

current speed on this location was $20-30 \mathrm{~cm} \mathrm{~s}^{-1}$, but this was only observed for a short period of time (Mortensen et al. 2014b). The highest average wave heights on location 1 were $0.9 \mathrm{~m}$, and therefore, the location was considered to be sheltered, both with regard to current speed and wave heights.

Location 2 was defined as the current exposed location with an overall current speed of $>20 \mathrm{~cm} \mathrm{~s}^{-1}$ and occasional current speeds of $>40 \mathrm{~cm} \mathrm{~s}^{-1}$, however, not maintained for long periods of time (Larsen 1999). The highest average wave heights on location 2 were $0.9 \mathrm{~m}$, and therefore, current speed was considered to be the most important exposure factor on this location.

Location 3 was defined as the wave exposed location with a current speed of $<10 \mathrm{~cm} \mathrm{~s}^{-1}$ approx. half of the time and an overall current speed of $<20 \mathrm{~cm} \mathrm{~s}^{-1}$. Single observations on current speeds of $40-60 \mathrm{~cm} \mathrm{~s}^{-1}$ were reported (Mortensen et al. 2014a). The highest average wave heights on location 3 were $2.2 \mathrm{~m}$, and therefore, wave height was considered to be the most important exposure factor on this location.

A CTD profile was taken on the three locations on the 10th of April to record salinity, temperature and oxygen levels, and no differences were found between the locations.

\section{Sampling and analyses}

Saccharina latissima individuals were sampled approx. every third week (depending on weather) at the three cultivation locations from April to August 2015. Three samples $(n=3)$ consisting of ten $S$. latissima individuals were sampled from each of three single droplines at each location on each sampling day. Three droplines were randomly selected during each sampling. Total length, length of lamina, width of lamina and total weight were measured for each sampled individual on the sampling day, and then the samples were frozen (approx. $-18{ }^{\circ} \mathrm{C}$ ) in food approved plastic bags until further analysis. All S. latissima samples were freeze-dried and then homogenized in a knifetec 1095 Sample Mill from Foss Tecator. The dried and homogenized samples were stored at $-18{ }^{\circ} \mathrm{C}$ in small plastic sample flasks. All chemical analyses were carried out in duplicate on each of the three samples. Dry weight was determined after vaporization of water at 102 $105^{\circ} \mathrm{C}$ for $>20 \mathrm{~h}$. 
The traditional Kjeldahl method was used to quantify the total Kjeldahl nitrogen, which is the organic N (e.g. in proteins) and ammonium $\mathrm{N}$ content in the seaweed samples (Oehlenschläger 1997).

Nitrate $\left(\mathrm{NO}_{3}{ }^{-}\right)$concentration was determined by ion chromatography. The method used was modified from Siu and Henshall (1998) that was developed for meat. Nitrate was extracted from $S$. latissima in MilliQ-water by sonication for $15 \mathrm{~min}$. The samples were centrifuged (3600 rpm for $10 \mathrm{~min}$ ), and the supernatant was cleansed in a C-18 SPE (solid phase extraction) column (chromabond, C18 EC $500 \mathrm{mg}$ per $6 \mathrm{~mL}$ ). The filtrate was transferred to a HPLC vial, and in order to keep the nitrate in its ionized form, $1 \mathrm{mM} \mathrm{NaOH}$ was added. The sample was run on a HPLC, Agilent, using $50 \mathrm{mM} \mathrm{NaOH}$ and MilliQ-water as the mobile phases. The nitrate was detected at ion chromatographic separation at 210/225 nm UV absorbance. Standard curves were prepared from sodiumnitrate stock solution (dry sodium nitrite and $1 \mathrm{mM} \mathrm{NaOH}$ ).

\section{Amino acids}

The amino acid composition was analysed using a Phenomenex (USA) EZ:faast amino acid analysis kit. The samples were first hydrolysed in $6 \mathrm{M} \mathrm{HCl}$ in a microwave oven (Microwave 3000 SOLV, Anton Paar, Austria) for $60 \mathrm{~min}$ at $110^{\circ} \mathrm{C}$. Following the instructions in the EZ:faast user manual, a clean-up step to remove matrix interferences and amino acid derivatization was performed. The amino acid composition was determined by liquid chromatography with a mass spectrometry detector (Agilent 1100 series, LC/MSD Trap, Agilent Technologies, Denmark) using a Z:faast $4 \mathrm{u}$ AAA-MS column $(250 \times 3.0 \mathrm{~mm}$, Phenomenex, USA $)$. The total protein concentration in the samples was calculated by summarizing all the amino acids and subtracting the water incorporated during hydrolysis (18 $\mathrm{g} \mathrm{H}_{2} \mathrm{O} \mathrm{mol}{ }^{-1}$ amino acid).

\section{Nitrate concentration in seawater}

Water samples (approx. $0.5 \mathrm{~m}$ below the water surface) were also collected in 200-mL plastic bottles at each site during each sampling of $S$. latissimia. Twelve drops of chloroform were added to the water samples for preservation, and they were stored in a cool and dark shed until analysis. The samples were analysed for nitrate content at Havstovan (Faroese Marine Research Institute) on an autoanalyser according to Grasshoff et al. (1999).

\section{Statistical analyses}

Data collection and calculation from raw data to values per gram dry weight (DW) were carried out in Excel. The statistical analyses were carried out in SAS Enterprise Guide 7.1, and the data was checked for normality using QQ-plots. Two- way ANOVA analysis was used to analyse the influence of season and the influence of cultivation and harvesting site on various investigated factors. One-way ANOVA analysis was used when only one factor was analysed. The ANOVA analyses were carried out on the arithmetic mean. When the twoway ANOVA showed $F$ values of significance, the individual means were compared using Tukey's HSD (honest significant difference) post hoc test $(P<0.05)$.

\section{Calculations}

The specific growth rate (SGR) was calculated as: $\mathrm{SGR}=\left(\ln \left(\right.\right.$ biomass $\left._{\mathrm{t}}\right)-\ln \left(\right.$ biomass $\left.\left._{0}\right)\right) / \mathrm{t}$, where biomass $_{t}=$ weight at time $t$, biomass $_{0}=$ weight at time zero and $t=$ time passed in days.

The essential amino acid score (EAA score) was calculated as follows (FAO/WHO, 1991):

$$
\begin{aligned}
& \text { EAA score }[\%] \\
& \begin{aligned}
= & (\mathrm{g} \text { of EAA in } 100 \mathrm{~g} \text { protein }) \\
& \quad /(\mathrm{g} \text { EAA in } 100 \mathrm{~g} \text { of reference pattern protein })
\end{aligned}
\end{aligned}
$$

Using the requirement pattern for 1- to 2-year-old children provided by WHO/FAO/UNU (2007) as reference, the score was based on the limiting amino acid in the sample.

\section{Results}

\section{Growth}

The lines seeded with $S$. latissima sporophyte culture were deployed on 3 March (day 0) and the first indications of growth were observed on 10 April (day 38). On 29 April (day 57), the first samples were collected from the sheltered and current exposed locations, but with no growth observed on the wave exposed location. The first sampling from the wave exposed location was carried out on 27 May (day 85). The last sampling from all three sites was on 19 August (day 170), when the produced biomass was harvested. No significant difference was observed in the total length of the S. latissima individuals cultivated at the different exposures (Fig. 2a). The individuals cultivated at the sheltered location had a significantly lower weight compared to the individuals cultivated on the current exposed location (Fig. 2b). No significant differences were observed between the weight of the individuals cultivated on the sheltered and wave exposed locations and between the individuals cultivated on the current exposed and wave exposed locations. The increase in weight was fitted to an exponential growth giving $R^{2}$ (coefficient of determination) of $0.847,0.8511$ and 0.954 for the sheltered 

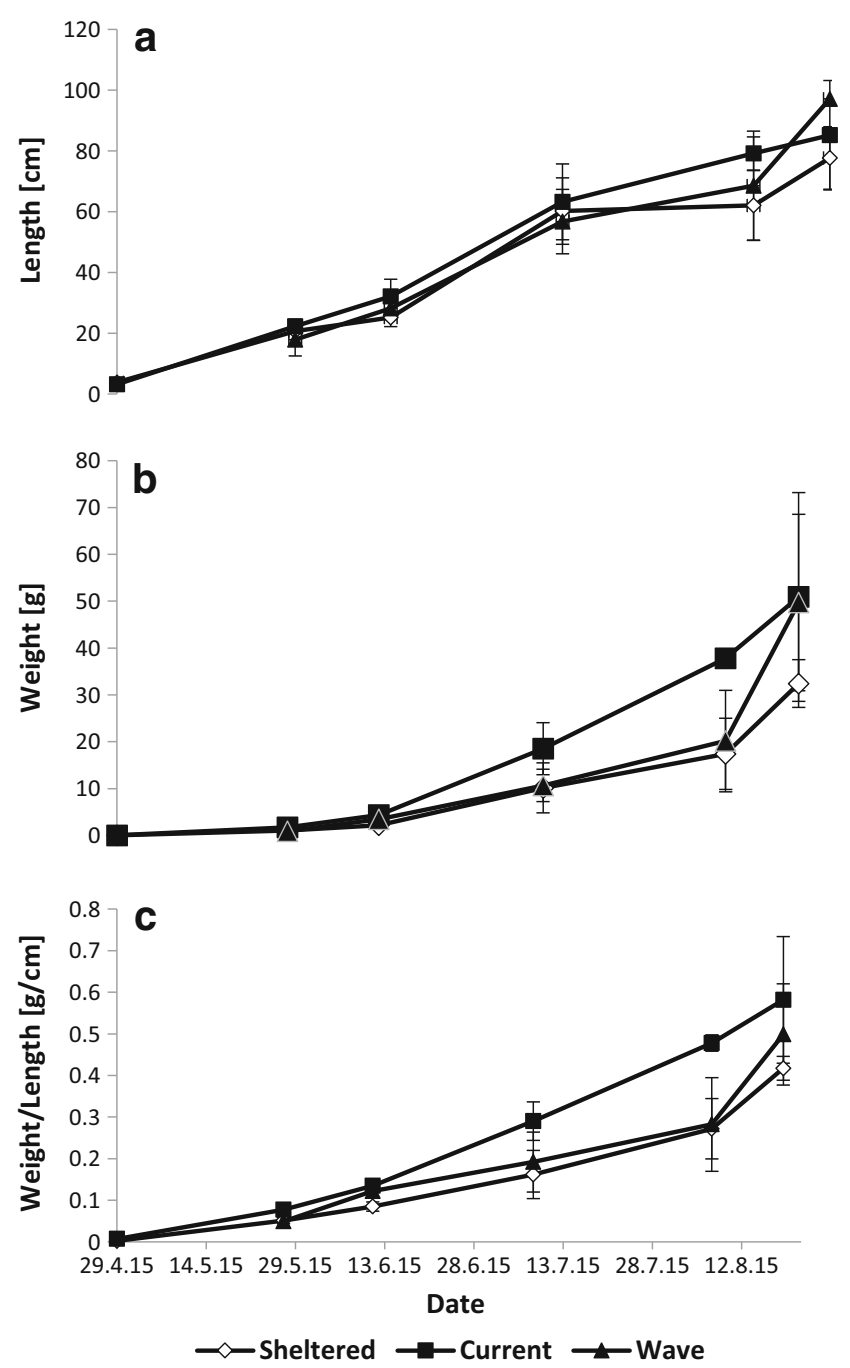

Fig. 2 Length growth, weight of the $S$. latissima individuals, and weight to length ratio at the three different cultivation locations (mean \pm std. deviation $n=3$ ). a No significant difference was observed in the total length at the different exposures. b The individuals cultivated at the sheltered location had a significantly lower weight compared to the individuals cultivated on the current exposed location. c Significant differences were observed between all three locations

location, current exposed location and the wave exposed location, respectively.

The specific growth rate (SGR) of the entire cultivation period with observable sporophytes (from 29 April to 19 August) was 0.068 day $^{-1}$ for the sheltered and current exposed locations and $0.069 \mathrm{day}^{-1}$ for the wave exposed location. On the wave exposed location, biomass $s_{0}$ was assumed to be the average of biomass $s_{0}$ for the sheltered and current exposed locations.

The weight to length ratio (Fig. 2c) showed significant differences between all three locations with the highest ratio at the current exposed location and the lowest at the sheltered location. The ratio was lowest in the juvenile individuals sampled on 29 April. During the growth period, the stipe represented a significantly higher percentage of the thallus length in the individuals cultivated on the sheltered location (4.8-11.6\%) compared to the current exposed (5.7-7.4\%) and wave exposed (4.3-7.9\%) locations. The lamina width to length ratio was also significantly lower in the individuals cultivated on the sheltered location (0.16-0.10) compared to the current exposed $(0.19-0.15)$ and wave exposed $(0.21-$ 0.12) locations.

Biofouling was first observed at the current exposed location on 11 June. The bryozoan species Membranipora membranacea was observed on a few individuals. On 7 August, biofouling was observed on individuals from all three locations, and the fouling was characterized by M. membranacea and the hydrozoan species Obelia geniculata. At the sheltered and wave exposed locations, nearly all examined individuals were more fouled compared to the individuals from the current exposed location. The biofouling was not quantified, and therefore, we will not deal with this further.

\section{Harvest}

The ropes were harvested on 19 August, and the total yield from the $30 \mathrm{~m}$ of seeded rope was $231 \mathrm{~kg}$ wet weight (ww) and 99,52 and $80 \mathrm{~kg}$ at the sheltered, current exposed and wave exposed, respectively. The yield at the current exposed location was $5.2 \pm 0.4 \mathrm{~kg} \mathrm{~m}^{-1}$ rope and was significantly lower than the yields at the sheltered and wave exposed locations, which were $9.9 \pm 1.5$ and $8.0 \pm 1.7 \mathrm{~kg} \mathrm{~m}^{-1}$, respectively.

\section{Nitrate in the seawater}

The nitrate measured in the seawater had the highest concentration at all three cultivation locations at the time of deployment (Fig. 3), with a concentration of 9.7, 11.7 and $11.5 \mu \mathrm{mol} \mathrm{L}{ }^{-1}$ at the sheltered, current exposed and wave exposed locations, respectively. The nitrate concentration decreased throughout the cultivation period and reached a minimum in August. The nitrate concentration reached

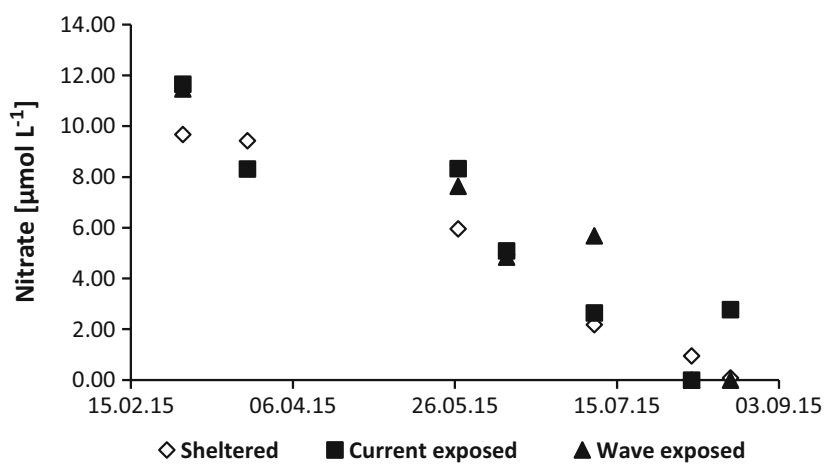

Fig. 3 Seasonal variation in nitrate levels in the seawater at the sheltered, current exposed, and wave exposed locations 
$0 \mu \mathrm{mol} \mathrm{L}{ }^{-1}$ at the current exposed and wave exposed locations early in August, while it reached $0 \mu \mathrm{mol} \mathrm{L}{ }^{-1}$ at the sheltered location at the time of harvest. At the current exposed location, the nitrate concentration had then increased again to $2.8 \mu \mathrm{mol} \mathrm{L}^{-1}$ at the time of harvest.

\section{Total Kjeldahl nitrogen and nitrate}

The total Kjeldahl nitrogen concentrations measured in the cultivated $S$. latissima from the three cultivation locations were significantly higher in the samples collected on 27 May and on 7 August compared to the samples from 8 July, and no significant differences were observed between the cultivation locations (Fig. 4).

The nitrate concentration in the biomass was significantly lower in the samples collected on the 27 May and on the 7 August compared to the samples collected on the 8 July; however, the standard deviation on the nitrate concentrations from the sheltered and wave exposed locations was very high, 78 and 66\%, respectively (Fig. 5). No significant differences in nitrate concentrations were found between the samples from the three cultivation locations.

\section{Protein content and amino acid composition}

The protein concentrations were significantly higher in the biomass samples collected on 29 April and 27 May compared to the samples collected on 8 July and 7 August, but no significant difference in protein concentrations was observed between the biomass from the three cultivation locations (Fig. 6).

The largest fraction of the amino acids was glutamic acid at all dates and locations, and the highest concentrations were found in July (Table 1). In most samples, the second largest fraction was aspartic acid; however, methionine represented a larger fraction than aspartic acid in July. Leucine was the

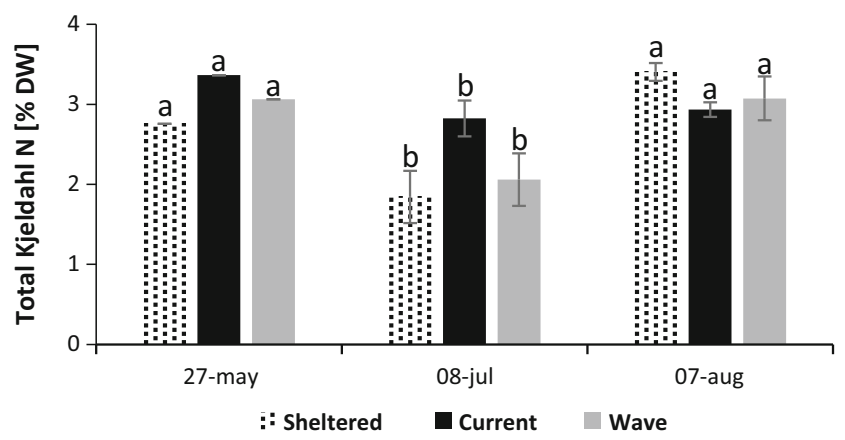

Fig. 4 Seasonal variation in total Kjeldahl nitrogen in S. latissima at the sheltered, current exposed, and wave exposed locations. The levels were significantly higher in the samples collected on the 27th of May and on the 7th of August compared to the samples from the 8th of July. Different letters indicate significant differences according to Tukey's HSD test (mean \pm std. deviation $n=3$ except for the 27th of May when $n=1$ )

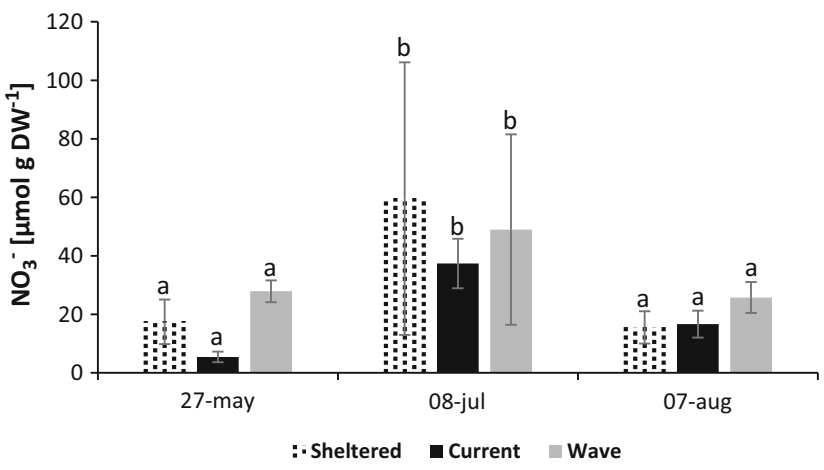

Fig. 5 Seasonal variation in nitrate content in S. latissima at the sheltered, current exposed, and wave exposed locations. The nitrate level was significantly lower in the samples collected on the 27th of May and on the 7th of August compared to the samples collected on the 8th of July. Different letters indicate significant differences according to Tukey's HSD test (mean \pm std. deviation $n=3$ except for the 27th of May when $n=2$ )

second largest fraction of the amino acids in the samples from 29 April and represented the second largest fraction in the samples from the wave exposed location on 27 May. Overall, the sums of essential amino acids (EAA) were from 30.2 to $41.9 \%$, with the exception of the samples from the current exposed location collected on 29 April, where the sum of EAA was $48.8 \%$. The highest EAA score (Fig. 7) was observed in the samples from the sheltered location on 27 May (93.7\%), and the lowest EAA score was observed in the samples from the wave exposed location sampled on 7 August (23.8\%). However, no significant difference was observed in the EAA between the tree locations.

\section{Discussion}

Saccharina latissima was cultivated successfully at both the sheltered, current exposed and wave exposed locations. The

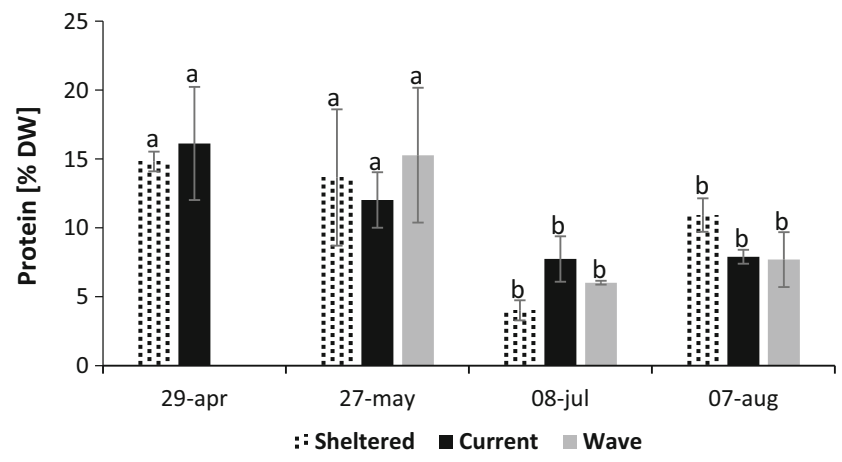

Fig. 6 Seasonal variation in protein content ( AA) of cultivated S. latissima at the sheltered, current exposed, and wave exposed locations. The protein level was significantly higher in the samples collected on the 29th of April and 27th of May compared to the samples collected on the 8th of July and 7th of August. Different letters indicate significant differences according to Tukey's HSD test (mean \pm std. deviation $n=3$ except for the 27th of May when $n=1$ ) 


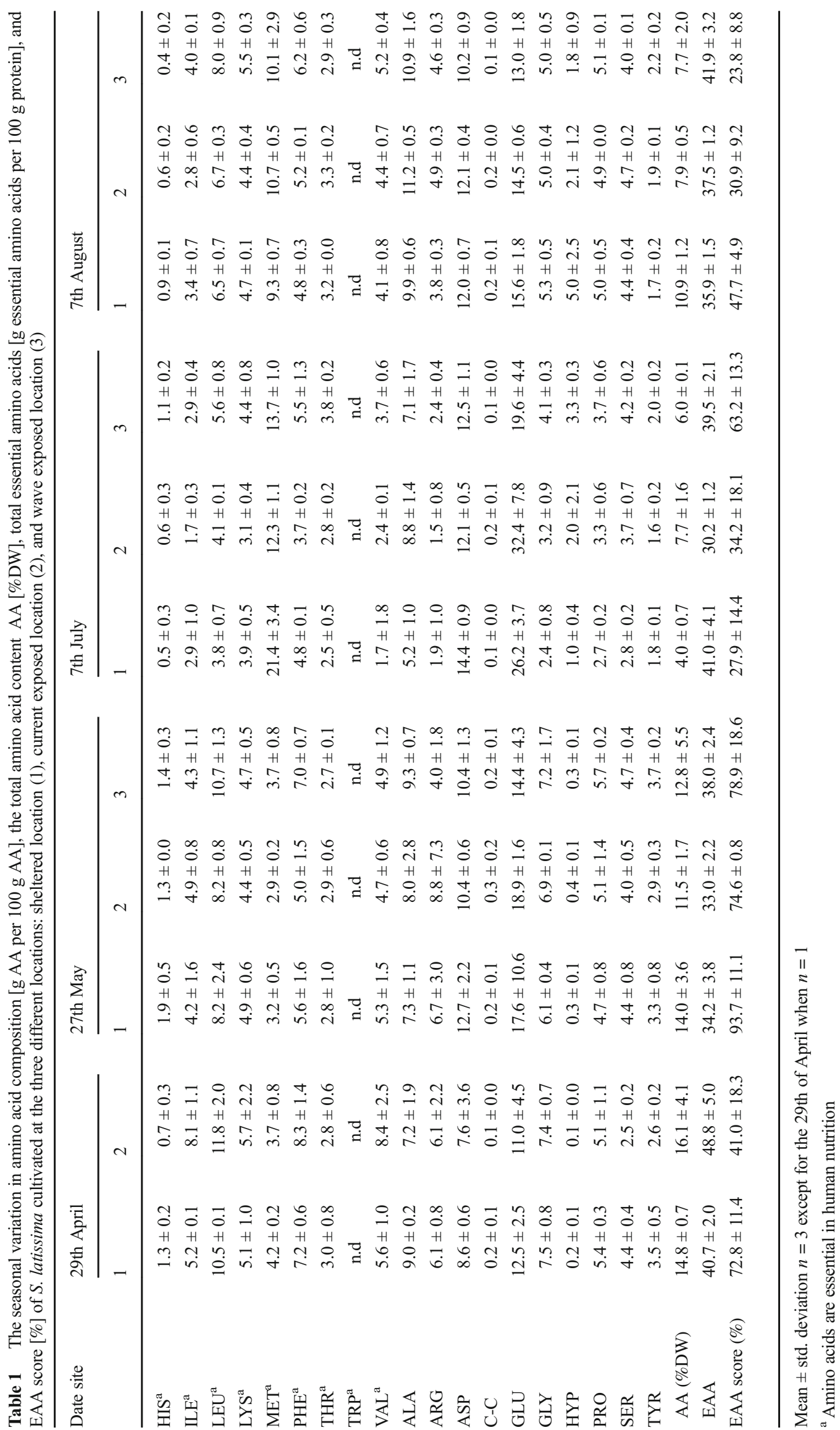




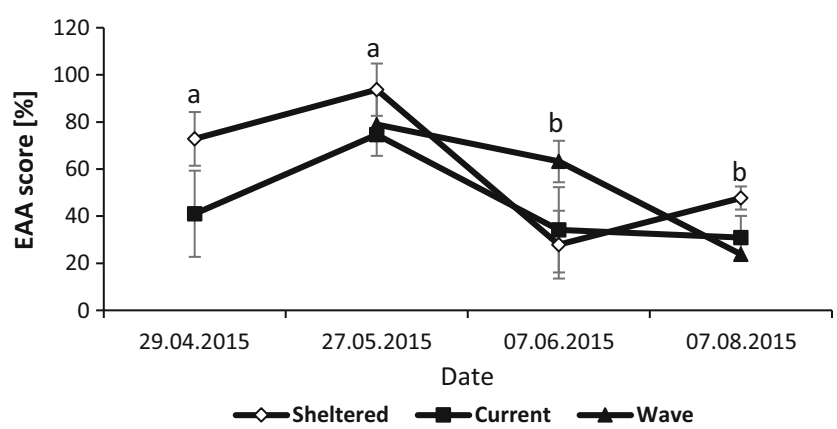

Fig. 7 The EAA score for $S$. latissima cultivated on the three locations. Different letters indicate significant differences in EAA score according to Tukey's HSD test (mean \pm std. deviation $n=3$ except for the 29th of April when $n=1$ )

sporophyte culture was sprayed directly onto the droplines right before deployment, skipping space and time of the demanding hatchery phase (from spore unit to germinating sporophyte on collectors or ropes), and the entwining process of the collectors around the dropline (e.g. Edwards and Watson 2011; Handå et al. 2013). We carried out the entire hatchery development from spore to juvenile sporophytes in culture flasks saving the space in the hatchery that the collectors or ropes would otherwise have demanded.

The yield per meter of cultivation rope found in our work was well within the range of $3-28 \mathrm{~kg} \mathrm{~m}^{-1}$ reported by others (Kraan 2013). The significantly higher weight of the individuals cultivated on the current exposed location was not reflected in the total yield. The current exposed location had a significantly lower yield of $5.2 \mathrm{~kg} \mathrm{~m}^{-1}$ compared to the yields at the sheltered and wave exposed locations, which were nearly twice as high. Peteiro and Freire (2013) compared the yield from a moderately exposed location $\left(30 \mathrm{~cm} \mathrm{~s}^{-1}\right)$ and a sheltered location $\left(10 \mathrm{~cm} \mathrm{~s}^{-1}\right)$ in a bay in North West Spain. The results from their work showed a higher yield at the moderately exposed location (16.1 $\pm 1.3 \mathrm{~kg} \mathrm{ww} \mathrm{m}^{-1}$ rope) compared to the sheltered location $\left(12.2 \pm 1.1 \mathrm{~kg} \mathrm{ww} \mathrm{m}^{-1}\right.$ rope). Overall, the yields found in Peteiro and Freire (2013) were higher than the yields found in our work; however, our study did not find a positive relationship between current exposure and yield, even though both studies worked within comparable current speeds. A reason for the lower yield in our work, especially at the current exposed location, can be the applied seeding method. The direct seeding method does not allow for holdfast development prior to deployment, and it is possible that many sporophytes are washed off the rope after deployment. The direct seeding method can very well have its limitations, especially at exposed locations, and could result in unequal population densities on the ropes.

Based on our results, exposure was not found to have an effect on the length growth; however, the weight of the individuals was significantly higher at the current exposed location compared to the sheltered and wave exposed locations. One explanation could be that a lower density of individuals on the ropes at the current exposed location due to more individuals being washed off the rope after deployment resulted in more space to develop heavier individuals. According to Buck and Buchholz (2005) S. latissima can withstand current speeds of up to $1520 \mathrm{~mm} \mathrm{~s}^{-1}$. The current exposed location used in this study rarely reached above $400 \mathrm{~mm} \mathrm{~s}^{-1}\left(40 \mathrm{~cm} \mathrm{~s}^{-1}\right)$ and was therefore not expect to limit the growth. Gerard (1982) reported that water motions of $25 \mathrm{~mm} \mathrm{~s}^{-1}$ were sufficient to saturate nutrient uptake of macroalgae. The current speed at our sheltered location was approx. $50 \mathrm{~mm} \mathrm{~s}^{-1}\left(5 \mathrm{~cm} \mathrm{~s}^{-1}\right)$ for about half of the time, and therefore, water motion was not expected to limit the growth either.

Studies on S. latissima have found that individuals growing at sheltered locations have a wide, ruffled and thin lamina, while individuals growing at exposed locations have a narrow, flat and thick lamina (e.g. Gerard et al. 1987; Parke 1948). Based on our results, the individuals cultivated at the current exposed location had the thickest and broadest lamina and shortest stipe. The significantly longer stipe to thallus ratio found at the sheltered location compared to both the current exposed and wave exposed locations corresponds well with the findings of Lüning (1990).

The chemical analyses carried out in this work are the first attempt to chemically characterize $S$. latissima cultivated in the Faroe Islands and also the first attempt to characterize the possible effect and correlation of exposure (sheltered, current exposed and wave exposed) and seasonality on the chemical composition. Overall, our results showed that exposure did not affect total Kjeldahl nitrogen, nitrate concentration, protein content, amino acid composition or essential amino acid score. However, seasonality seemed to have an effect.

Our results showed that total Kjeldahl nitrogen was significantly lower in July compared to May and August, while the nitrate concentration in the biomass was significantly higher in July compared to May and August. Even though the total Kjeldahl nitrogen reached the same concentrations in May and August, the available nitrate in the surrounding seawater was very low in August compared to May. The likely explanation is that the relatively high concentration of nitrate found in the S. latissima tissue in July was reduced and allocated into the organic $\mathrm{N}$ fraction in August.

The protein concentrations (based on the sum of the amino acids) were highest in the spring and significantly lower in the summer, which was in agreement with the fluctuations of nitrate concentrations in the seawater. The concentrations found in our study fluctuated similarly with regard to seasonality as found in Scottish waters (Schiener et al. 2015). However, our measurements did not fall within their measured range. Our lowest concentration of $4.0 \% \mathrm{DW}$ measured in July was lower compared to their lowest concentration of $5.1 \% \mathrm{DW}$ measured in October, and our highest concentration of $16.1 \%$ DW in April was higher compared to their highest 
concentration of 9.9\% DW measured in March. One explanation for the higher concentration measured in our work could be that our measurements were based on cultured biomass and Schiener et al. (2015) reported from natural populations. This agrees with unpublished work from the Faroe Islands that found protein concentrations to be significantly higher in the cultured biomass compared to natural populations (E. á Geilini Ortind pers. obs). Another reason could be that Schiener et al. (2015) used a different protein analysing method than we used. Marinho et al. (2015) reported overall lower protein concentrations from cultivated $S$. latissima in Denmark compared to our measurements. The lowest protein concentration of $1.3 \%$ DW was measured in May and the highest concentration of $10.8 \% \mathrm{DW}$ in November. The protein analysis in Marinho et al. (2015) was carried out using the same method as we used in the current work (sum of amino acids), and even though we did not report any measurements from November, there seemed to be a different seasonality for protein concentration fluctuation in Danish and Faroese cultivated S. latissima.

The nutritional value of the protein was estimated using the EAA score. The scores were significantly lower during the summer period compared to spring, with measurements ranging from 23.8 to $63.2 \%$ and 41.0 to $93.7 \%$, respectively. The EAA scores on cultivated $S$. latissima reported by Marinho et al. (2015) were slightly lower with a maximum score of $68.9 \%$ measured in November and a minimum of $16.7 \%$ measured in September. The limiting amino acid in this study was mainly found to be histidine, which agrees with that reported by Marinho et al. (2015). In two samples from April, lysine was the limiting amino acid, which Murata and Nakazoe (2001) also reported to be the limiting EAA in S. latissima. Similar to what is reported in the literature, the largest amino acid fractions in the analysed $S$. latissima in this study were glutamic and aspartic acid (Fleurence 1999; MacArtain et al. 2007; Marinho et al. 2015).

In conclusion, this work found that exposure did have an effect on the morphology of the cultivated S. latissima, and the individuals cultured at the current exposed location had a significantly thicker lamina compared to the individuals cultured at the sheltered and wave exposed locations. However, the overall yield was significantly lower at the current exposed location compared to the other two locations. We can conclude that the described direct seeding method can be used within the farm conditions of this work, and the method is worth considering due to time and space efficiency. However, future work and optimization must determine if the direct seeding method can be as successful as the more traditional methods using collectors and furthermore if the method can be used at current exposed locations.

Exposure did not have an effect on Kjeldahl nitrogen, nitrate and protein concentration of the biomass nor on the nutritional quality of the proteins. Seasonality did, however, have an effect on these factors. The quality of the produced biomass was highest in the spring. Based on the results found in the current work, the recommendation with regard to S. latissima for human consumption would be to harvest the cultured biomass in the Faroe Islands in late May or early June. During this period of the year, the produce will have a high nutritional value without any unwanted biofouling. To be able to harvest a high yield in May/June, it is necessary to deploy the seeded ropes earlier than in this study. From previous work and experience, we know that it is possible to deploy in January (Wegeberg et al. 2013; A. MolsMortensen pers. obs.), and to have an even longer cultivation period, it may be better to deploy already during autumn after the summer biofouling period.

Acknowledgements The work was financed by FiskaalingAquaculture Research Station of the Faroes. We would like to thank Øystein Patursson, Esbern Patursson and Signar Pætursson Dam for their help with the cultivation structures and boat transport, Erna Joensen and Heðin Abrahamsen for drawing the map and Mortan Mols Mortensen for diving assistance, $\mathrm{PhD}$ student Sabrine Tauber Pedersen and Laboratory Technician Inge Holmberg for assistance on analyses.

Open Access This article is distributed under the terms of the Creative Commons Attribution 4.0 International License (http:// creativecommons.org/licenses/by/4.0/), which permits unrestricted use, distribution, and reproduction in any medium, provided you give appropriate credit to the original author(s) and the source, provide a link to the Creative Commons license, and indicate if changes were made.

\section{References}

Bolton JJ, Lüning K (1982) Optimal growth and maximal survival temperatures of Atlantic Laminaria species (Phaeophyta) in culture. Mar Biol 66:89-94

Buck BH, Buchholz CM (2005) Response of offshore culitvated Laminaria saccharina to hydrodynamic forcing in the North Sea. Aquaculture 250:674-691

Debes H, Gaard E, Hansen B (2008) Primary production on the Faroe shelf: temporal variability and environmental influences. J Mar Syst 74:686-697

Edwards M, Watson L (2011) Cultivating Laminaria digitata. Irish Sea fisheries board. Aquaculture Explained 26. pp. 72

ENVOFAR (2015) Oceanography - time series: [Accessed: 7 Sept 2015]. http://www.envofar.fo/index.php?page=climate

Fleurence J (1999) Seaweed proteins: biochemical, nutritional aspects and potential uses. Trends Food Sci Technol 10:25-28

Fortes MD, Lüning K (1980) Growth rates of North Sea macroalgae in relation to temperature, irradiance and photoperiod. Helgo Meeresunters 34:15-29

Gaard E, Gislason A, Melle W (2006) Iceland, Faroe and Norwegian coasts. In Robinson AR, Brink KH (eds), The sea. The Global Coastal Ocean. Interdisciplinary Regional Studies and Syntheses: President and Fellowship of Harvard University Vol. 14 Part B pp. $1077-1109$

Gaard E, á Norði G, Simonsen K (2011) Environmental effects on phytoplankton production in a Northeast Atlantic fjord, Faroe Islands. J Plankton Res 33:947-959

Gerard VA (1982) In situ waer motion and nutrient uptake by giant kelp Macrocystis pyrifera. Mar Biol 69:51-54 
Gerard VA, DuBois K, Greene R (1987) Growth responses of two Laminaria saccharina populations to environmental variation. Hydrobiologia 151(152):229-232

Grasshoff K, Kremling K, Ehrhardt M (1999) Methods for seawater analysis, 3rd edn. Wiley-VCH, Weinheim

Handå A, Forbord S, Wang X, Broch OJ, Dahle SW, Størseth TR, Reitan KI, Olsen Y, Skjermo J (2013) Seasonal- and depth-dependent growth of cultivated kelp (Saccharina latissima) in close proximity to salmon (Salmo salar) aquaculture in Norway. Aquaculture 414415:191-201

Hansen B, Eliasen SK, Gaard E, Larsen KMH (2005) Climatic effects on plankton and productivity on the Faroe shelf. ICES J Mar Sci 62: 1224-1232

Holdt SL, Kraan S (2011) Bioactive compounds in seaweed: functional food applications and legislation. J Appl Phycol 23:543-597

Hughes AD, Kelly MS, Black KD, Stanley MS (2012) Biogas from Macroalgae: is it time to revisit the idea? Biotechnol Biofuels 5:86

Hurd CL (2000) Water motion, marine macroalgal physiology and production. J Phycol 36:453-472

Kraan S (2013) Mass-cultivation of carbohydrate rich macroalgae, a possible solution for sustainable biofuel production. Mitig Adapt Strateg Glob Chang 18:27-46

Larsen KMH (1999) Current meter observations in Faroese inshore waters 1979-1998. Technical report, The Faroese Fisheries Laboratory, Tórshavn

Lee JA, Brinkhuis BH (1986) Reproductive phenology of Laminaria saccharina (L.) Lamour. (Phaeophyta) at the southern limit of its distribution in the northwestern Atlantic Ocean. J Phycol 22:276285

Lüning K (1990) Seaweeds. Their environment, biogeography and ecophysiology. John Wiley \& Sons, New York

Lüning K, Freshwater W (1988) Temperature tolerance of Northeast Pacific marine algae. J Phycol 24:310-315

MacArtain P, Gill CIR, Brooks M, Campbell R, Rowland IR (2007) Nutritional value of edible seaweeds. Nutr Rev 65:535-543

Marinho GS, Holdt SL, Angelidaki I (2015) Seasonal variations in the amino acid profile and protein nutritional value of Saccharina latissima cultivated in a commercial IMTA system. J Appl Phycol 27:1991-2000
Mortensen E, Nielsdóttir MC, Larsen KMH, Patursson O, Simonsen, K. (2014a) Current measurments in the ASAF project deployment SUSC1307. Technical report ASAF nr. 14-05, Havstovan and Fiskaaling, Tórshavn

Mortensen E, Nielsdóttir MC, Larsen KMH, Patursson O, Simonsen K (2014b) Current measurments in the ASAF project deployment SUSC1307. Technical report ASAF nr. 14-06, Havstovan and Fiskaaling, Tórshavn

Murata M, Nakazoe J (2001) Production and use of marine algae in Japan. Jpn Agric Res Q 35(4):281-290

Oehlenschläger J (1997) WEFTA interlaboratory comparison on nitrogen determination by Kjeldahl digestion in fishery products and standard substances. Inf Fischwirtsch Fischereiforsch 44(1):31-37

Parke M (1948) Studies on British Laminariaceae. I. Growth in Laminaria saccharina (L.) Lamour. J Mar Biol Assoc U K 27: 651-709

Peteiro C, Freire Ó (2013) Biomass yield and morpholological features of the seaweed Saccharina latissima cultivated at two different sites in a costal bay in the Atlantic coast of Spain. J Appl Phycol 25:205213

Schiener P, Black KD, Stanley MS, Green DH (2015) The seasonal variation in the chemical composition of the kelp species Laminaria digitata, Laminaria hyperborea, Saccharina latissima and Alaria esculenta. J Appl Phycol 27:363-373

Simonsen K (2015) Tøl fyri vind, rák og aldu á aliøkinum við Fossá í Sundalagnum (A32). Technical report, Fiskaaling, Hvalvík

Siu DC, Henshall A (1998) Ion chromatographic determination of nitrate and nitrite in meat products. J Chromatogr A 804:157-160

Wegeberg S, Mols-Mortensen A, Engell-Sørensen K (2013) Integreret akvakultur i Grønland og på Færøerne. Videnskabelig rapport fra DCE - Nationalt Center for Miljø og Energi 82

FAO/WHO 1991 Protein quality evaluation. Report of the joint FAO/ WHO Expert Consultation. Food and Nutrition Paper No. 51. Technical report FAO/WHO, Rome

WHO, FAO, UNU Expert Consultation (2007) Protein and amino acid requirements in human nutrition. Technical report $935 \mathrm{WHO} / \mathrm{FAO} /$ UNU 